\title{
ON THE ISSUE OF INCREASING COMPETITIVENESS OF GEORGIAN REGIONS
}

\author{
AZA IPSHIRADZE \\ Associated Professor Ph.D. in Economy, \\ Kutaisi University, Georgia \\ aza.iphshiradze@unik.edu.ge
}

NANA RUSADZE

Associated Professor, Ph.D. in Public Administration,

Akaki Tsereteli State University, Georgia

nana.rusadze@atsu.edu.ge

\section{KEYWORDS: REGION, COMPETITION, EVALUATION, RANKING, INEQUALITY.}

For citation: Ipshiradze, A., Rusadze, N. (2019). On the Issueof Increasing Competitiveness of Georgian Regions, Globalization And Business, №8, pp. 105-109. https://doi.org/10.35945/gb.2019.08.012

\section{INTRODUCTION}

Attitude towards the regions has changed in conditions of Globalization process. The region has justly become a quasi-state, a quasi-corporation, a market space and a society. It is a fragmented subsystem of the national economy and a large object of certain property and economic activity. At the same time, the region creates an industrial environment, an area for farmers who have an important function on regulating the political and socio-economic development of a particular country. The area of the region is full of many organizations and communication systems (Kharaishvili, 2004:15).

"Competitiveness" is a term used with a wide range of spectrum and scales and it covers regions and countries as well. In Georgia, as in the developing country by means of market economic system principles, post-socialist transformations and the rapid rates of globalization process have made the regions of particular importance. Association Agreement between Georgia and Europe further broadens the possibility of economic independence of individual regions or administrative-territorial units.

Generally, regional competitiveness can be defined as the region's ability to provide high quality of life and income for population in the conditions of international competitiveness.

The necessity of increasing the region's competitiveness is primarily due to the generally recognized shortcomings and deformities of market economy functioning, as well as to the specificities of particular country's economic system, production development, natural-climatic, ethnographic and other types of features. That is why, at a time of solving economic, social, and other important tasks, in modern conditions, deter- mining the competitiveness of regions is of the utmost importance. It is impossible to scientifically determine and realize development prospects of the regions and main directions and to properly plan the processes taking place in the region, without comparing the regions, identifying potentials and measuring the attraction. The abovementioned is reflected in the region's development strategy, where the interests of the region must also be fixed. From a purely marketing standpoint, the region must be "passed off", "sold gainfully" to investors - for investment, to tourists - to increase interest, to potential residents - for the desire to live on their own territory.

\section{LITERATURE REVIEW}

Rationalistic, was formed as a science in the 50's of the 20th century. In scientific literature, at a time of researching the regional economic problems, more attention is paid to the study of problematic issues on regions including several countries (of Europe, Asia, South Caucasus, etc.) in individual territorial areas, ie the region is considered in the spatial economic hierarchy. However, these kinds of works also provide interesting findings on the problems of the country's region. Regional policies, the evaluation of economic growth of the regions, and the region's place in the national economy occupy an important place in Marion Temple's work "Regional Economics". The author discusses the components of regional economics and opportunities for regional growth in relation to the European Union (Temple, 1994).

In a fundamental work, "Regional Economics and Management", G. Fetisov and V. Oreshin discuss the approaches 
of different economic schools in terms of rational use of territory, the role and the place of economic policies in the rational organization of economic space, and offer some views on regional economic regulation (Fetisov and Oreshin, 2006).

The research of the problems of regional economics has become actual in Georgia since it gained the independence. Since the second half of the 1990s, new works have emerged on regional economics, including elements of regional policies. E. Kharaishvili's "Regional Economics" was dedicated to the study of economics of the regions of Georgia. The author discusses transformation of the regional economic structures, the regions' natural-resource potential, regional economic policies, and provides a regional analysis of the population's living level and working resources, investment and innovation activities and agro-industrial complex (Kharaishvili, 2004).

The work "On the Issue of Ranking Socio-Economic Development of the Regions of Georgia" highlights the necessity of widespread regionalization processes in almost every country that can solve economic, social and other urgent issues. The work shows the sharp difference and imbalance of the regions of Georgia. This study is an attempt to rank the socio-economic development of Georgian regions, it is one of the elements of regional diagnostics, which includes a wide range of regional situation and problem characteristics, a list of qualitative assessment of different factors that determine the situational condition and development (Chikhladze, 2015).

There are some works, that focus on studying the problems of a particular region, determining its role and place in the system of the national economy. For example, in the essay "Conditions and Prospects for the Development of Imereti Region", the authors are discussing the opportunities of the Georgian region - Imereti, determining competitive advantages, offering key directions for increasing the awareness and efficiency of the region's economy (Gavtadze and Chikhladze, 2009).

\section{RESEARCH METHODOLOGY}

The present work is based on studies of Georgian and foreign authors dedicated to regional competitiveness and their evaluation. Also the views of politicians and experts are used, as well as the reports of international organizations, surveys, seminar and scientific forum materials, applicable legislative acts both in Georgia and other foreign countries. Important information databases are presented by reliable internet resources, scientific publications and statistical databases published in international publications. General - scientific methods (synthesis, analysis, analogies, comparative, historical, quantitative, graphical, statistical and other methods) of the research are used in the article.

\section{MAIN PART}

In modern conditions, the challenge of sustainable economic growth in many countries around the world cannot be achieved without the development of the country's regions, for which the crucial precondition is to increase regional competitiveness.
Works and researches connected to the issues on regional competitiveness in foreign countries has particularly become active since the early 1980s. The problem of regional competitiveness has been addressed in many countries' state programs and they are working to resolve it.

According to the EU treaty, the country's economy is competitive if its population has quite high and growing standard of living and a high employment coefficient. The development of competitiveness of regions in the EU depends on the modernization and diversification of the industrial structure (development of science-based business activities and innovation), on the achievement of physical level of infrastructure and the appropriate level of human capital. Hereby, it is necessary to take the horizontal conditions into account, that are relevant to the sustainable development by means of having an impact on the environment (Grdzelishvili, 2019:184).

In Georgia, the administrative-territorial unit is considered as a region. At the level of self-administration, under the "region" is meant the municipalities and self-governing cities (67 self-governing units out of which 62 are municipalities and 5 self-governing cities). Municipalities are united in 9 regions (2 autonomous republics) that do not represent local self-administrative units. They only have coordinative and consulting functions between the self-administrative units and the Government of Georgia, where the Government is represented by the State Representative - the Governor, and the self-administrative unit - the Administrator/Mayor, the Chairman of the City Council and his / her Deputy. According to the constitution, the territorial arrangement of Georgia should take its final form after the full restoration of Georgian jurisdiction throughout the whole country. The territorial area, where the competence of the State Representative - Governors - is spread, are considered as a "region" at the level of administration. (Rusadze, 2018: 64)

In conditions of the abolition of centralized planning and transformation of the market system in Georgia, the pre-existing structure of manufacturing and regional inequality have become a major problem. By means of which the situation in this country is still difficult. Studies and works connected to competitiveness are being published, but their practical implementation level and received results are insufficient.

Many indicators can confirm this. One is the trade turnover according to regions, where the identified inequality is clearly shown in the figure below.

Figure. The curve expressing inequality of trade turnover between regions of Georgia

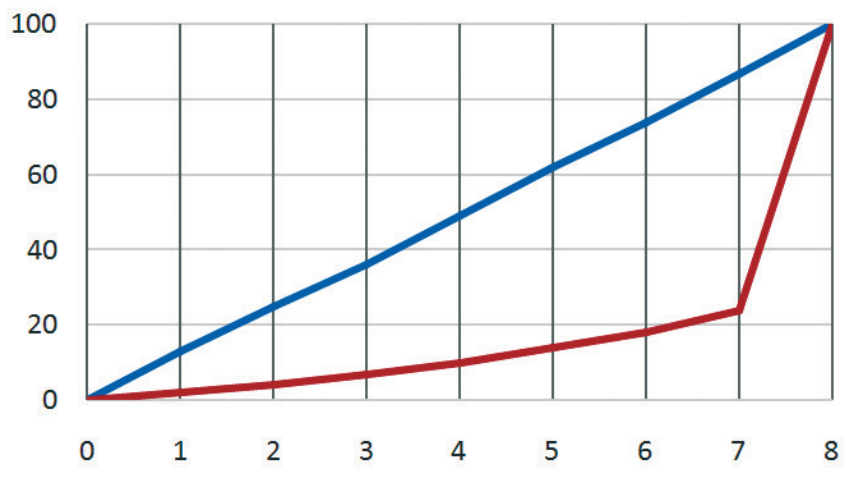


Based on data from the State Department of Statistics, we have calculated trade turnover indicators according to the regions. It turned out to be maximum in the capital city (Tbilisi), where one resident spends an average of $60 \mathrm{GEL}$ (about US \$20) a day, while the minimum is Racha-Lechkhumi in Lower Svaneti (2.5 GEL), or 24 times less.

In fact the same situation is observed according to other indicators as well (see table)

Table. Some generalized indicators calculated per person of the population

\begin{tabular}{|c|c|c|c|c|}
\hline Indicator & $\begin{array}{c}\text { Average } \\
\text { regional } \\
\text { indicator }\end{array}$ & $\begin{array}{c}\text { The ratio } \\
\text { between } \\
\text { minimum } \\
\text { and } \\
\text { maximum }\end{array}$ & $\begin{array}{c}\text { Number } \\
\text { of regions } \\
\text { where the } \\
\text { indicators } \\
\text { are below } \\
\text { average? }\end{array}$ & $\begin{array}{c}\text { Maximum } \\
\text { indicator }\end{array}$ \\
\hline $\begin{array}{c}\text { Direct foreign } \\
\text { investments (\$) }\end{array}$ & 512 & 65,9 & 9 & 1284,7 \\
\hline $\begin{array}{c}\text { Industry } \\
\text { turnover } \\
\text { (thousand GEL) }\end{array}$ & 3,3 & 8,7 & 8 & 5,2 \\
\hline $\begin{array}{c}\text { GPD (thousand } \\
\text { GEL) }\end{array}$ & 10,2 & 3,2 & 10 & 14,1 \\
\hline $\begin{array}{l}\text { Trade turnover } \\
\text { (thousand GEL) }\end{array}$ & 8,9 & 24,4 & 10 & 22,0 \\
\hline
\end{tabular}

Regional Development Program for 2018-2021 is functioning in Georgia, which is one of the key tools for achieving regional development policy goals. It offers a framework for coordinating the implementation of integrated territorial measures. It is noteworthy that the first priority of the program is to increase the competitiveness of the country and its regions and to improve basic infrastructure for the sustainable development (Ministry of Regional Development and Infrastructure of Georgia, 2019).

One of the ways to overcome inequality and the difficult socio-economic situation in the regions is to increase their competitiveness.

Competitiveness of the region is determined by the existence of one or more competitive sectors of the economy as well as the awareness of regional authorities to provide relevant conditions to regional enterprises in order to achieve and maintain competitive advantage in certain fields (Baratashvili, E., Gechbaia B. and Glonti V., 2012: 138).

Regional competitiveness, in its essence, is the competitiveness of a territorial unit, which has defined political and economic boundaries and fixes this difference compared to the competitiveness of different organizational structures. The competitiveness of the region shows the unity of relations connected to the economic development of the region with respect to other regions.

The study of the issue showed that the factors affecting competitiveness of the particular region can be grouped into the following groups:

1. Economic conditions - business sector development, demographic situation, economic structure, consumer market volume, social background, scale of real demand, trans- port-logistics potential, resource potential, prospects of economic growth;

2. Financial Flexibility - the amount and share of revenues of the local budget, awareness to finance expenses and future projects in total revenues, the skill and ability to make decisions in the field of finance, etc.;

3. Organizational-administrative structure - flexibility of the governance structure, awareness to adapt to a changing environment, creating conditions for public engagement and participation;

4. Intellectual potential - opportunities for scientific support of reforms, development of innovative projects, existence of research and higher educational institutions, formation and development potential of regional innovation system.

One part of researchers believe that in order to evaluate the competitiveness of regions, it is necessary to rank them. It allows us to use the results of the analysis not only as a basis, for evaluating investment attractiveness in the regions, but also for identifying the problems on solving of which the matter of increasing the competitiveness of a particular region and hence its development depends on (Chikhladze, 2015: 5).

In order to assess the competitiveness of regions, non-parametric methods are used in practice by means of which the integral coefficient of competitiveness of regions is determined. It ranges from 0 to 1 . According to this coefficient, it is possible to group regions by the level of competitiveness. Consequently, five groups of regions are separated at equal intervals. (Baratashvili, E., Gechbaia B. and Glonti V., 2012: 157).

Group - high level of competitiveness $<\mathrm{IK}<1$;

Group - sufficiently high level: $0,6<\mathrm{IK}<0,8$;

Group - average level: 0,4 <IK <0,6;

Group - low level: 0,2 <IK <0,4;

Group - noncompetitive regions: $0<1 \mathrm{~K}<0,2$.

\section{CONCLUSIONS}

Increasing the competitiveness of the regions and overcoming inequality existed in the regions should become the main target of the country's economic policy.

It is necessary to formulate new strategies in the regions of Georgia. Existing strategies have been worked out in 2013 and cover the periods of 2014-2021. New development strategies must be harmonized with the country's regional development strategy. The websites of regions and municipalities should also be improved for providing them with complete information;

One of the priority areas for improving the competitiveness of individual regions of Georgia can be considered their formation as transport and logistics hubs, which is conditioned by their potential of transport and strategic location. Such regions are considered to be: Imereti, Adjara Autonomous Republic, Samegrelo-Zemo Svaneti and Samtskhe-Javakheti. This way, the transport potential of the regions will also be used to support tourism. Technical characteristics of trans- 
port will be improved and transport vehicles (air and motor) will be added. This will increase the number of domestic tourists, as well as foreign tourists in the region and throughout Georgia;

Comprehensive information about the region's natural-resource potential will be prepared and sent to target groups. Geographical location of Georgian regions and diverse natural resources create favorable conditions for industrial development of the regions;

The opportunities of utilizing hydro resources will be used. Construction - exploitation of small and medium hydroelectric stations in separate regions and municipalities will take place. West Georgia's regions are rich in hydropower and mountain rivers, which can become a relatively cheap source of energy;

We consider that Georgia and its separate regions are inappropriately using the abilities of diplomatic economics, the same as the commercial diplomacy. In this regard positive shifts have been observed across the country (e.g., appointing commercial officers), but more efforts are needed to be made in the regions. Coordinating role in this matter should be played by the administrations of the governor, that can best identify the comparative advantage of the given area together with the municipalities.

\section{REFERENCES:}

1. Baratashvili, E., Gechbaia B. and Glonti V. (2012). Competetivness of Georgian Economy: Modern Challenges. Publishing House "Universali", Tbilisi. p.138

2. Chikhladze, N. (2015). On the issue of ranking socioeconomic development of Georgia's regions. Proceedings of the Academy of Economic Science of Georgia. Publishing House "Universali". p.5.

3. Fetisov, G. and Oreshin, V. (2006). Regional Economics and Management. "Infra-M" [online] Available at:< http://bwbooks.net/books/economic/fetisov-gg/2006/files/regionalnayaekonomika2006.pdf [Accessed 19 October 2019].

4. Gavtadze, G. and Chikhladze, N. (2009). Conditions and prospects of economic development of imereti region. Kutaisi. Publishing House of Akaki Tsereteli State University.

5. Grdzelishvili, N. (2019). Regional Policy of EU Countries. Publishing House "Universali", Tbilisi. p.184.

6. Kharaishvili, E. (2004). Regional Economics. Publishing House of Tbilisi State University. Tbilisi. p.15

7. Ministry of Regional Development and Infrastructure of Georgia. [online] Available at:<https://mrdi.gov.ge/ka/about/ \%E1\%83\%A1\%E1\%83\%90\%E1\%83\%A5\%E1\%83\%9B\%E1\%83\%98\%E1\%83\%90\%E1\%83\%9C\%E1\%83\%9D\%E1\%83\%91 \%E1\%83\%90/\%E1\%83\%A0\%E1\%83\%94\%E1\%83\%92\%E1\%83\%98\%E1\%83\%9D\%E1\%83\%9C\%E1\%83\%A3\%E1\%83\%9A \%E1\%83\%98\%20\%E1\%83\%92\%E1\%83\%90\%E1\%83\%9C\%E1\%83\%95\%E1\%83\%98\%E1\%83\%97\%E1\%83\%90\%E1\%83\%A0 \%E1\%83\%94\%E1\%83\%91\%E1\%83\%90 [Accessed 19 October 2019].

8. Rusadze, N. (2018). Main directions for improving the effectiveness of public administration. Publishing House of Akaki Tsereteli State University. p.64

9. Temple M., (1994). Regional Economics. Palgrave, London. [online] Available at:< https://link.springer.com/ book/10.1007/978-1-349-23364-9\#about [Accessed 19 October 2019]. 


\title{
ON THE ISSUE OF INCREASING COMPETITIVENESS OF GEORGIAN REGIONS
}

\author{
AZA IPSHIRADZE \\ Associated Professor Ph.D. in Economy, \\ Kutaisi University, Georgia \\ aza.iphshiradze@unik.edu.ge

\section{NANA RUSADZE} \\ Associated Professor, Ph.D. in Public Administration, \\ Akaki Tsereteli State University, Georgia \\ nana.rusadze@atsu.edu.ge
}

\section{KEYWORDS: REGION, COMPETITION, EVALUATION, RANKING, INEQUALITY.}

For citation: Ipshiradze, A., Rusadze, N. (2019). On the Issueof Increasing Competitiveness of Georgian Regions, Globalization And Business, №8, pp. 105-109. https://doi.org/10.35945/gb.2019.08.012

\section{SUMMARY}

Competitiveness is the central mechanism of market system, it is its locomotive. In the regions of post-Soviet countries, strict market demands are gradually being perceived as real and the perspective of long-term usage of an existed resource potential is being determined. However, post-socialist transformations and the rapid rates of globalization process have made the regions of particular importance. Our goal was to meet the basic conditions for identifying the competitiveness of Georgian regions and to present the prospect of its improvement.

The necessity of increasing the region's competitiveness is primarily due to the generally recognized shortcomings and deformities of market economy functioning, as well as to the specificities of particular country's economic system, production development, natural-climatic, ethnographic and other types of features. That is why, at a time of solving economic, social, and other important tasks, in modern conditions, determining the competitiveness of regions is of the utmost importance.

The research of the problems of regional economics has become actual in Georgia since it gained the independence. The present work is based on studies of Georgian and foreign authors dedicated to regional competitiveness and their evaluation.

Regional competitiveness, in its essence, is the competitiveness of a territorial unit, which has defined political and economic boundaries and fixes this difference compared to the competitiveness of different organizational structures. The competitiveness of the region shows the unity of relations connected to the economic development of the region with respect to other regions.

We consider that Increasing the competitiveness of the regions and overcoming inequality existed in the regions should become the main target of the country's economic policy. 